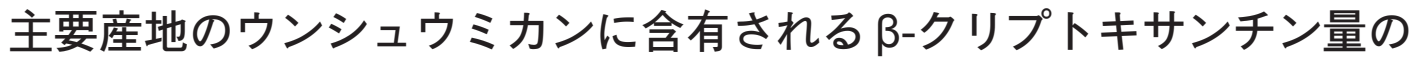 品種群間差およびその糖度との関連について
}

\author{
久永絢美・吉岡照高・杉浦 実 ${ }^{\mathrm{a} *}$ \\ 国立研究開発法人農業・食品産業技術総合研究機構果樹茶業研究部門カンキッ研究領域 \\ 424-0292 静岡市清水区興津中町
}

\section{Differences in Beta-cryptoxanthin Content among Various Kinds of Satsuma Mandarin (Citrus unshiu Marcow.) Harvested in Major Production Centers of Japan and the Relationship with Sugar Content}

\author{
Ayami Hisanaga, Terutaka Yoshioka and Minoru Sugiura ${ }^{\text {a* }}$ \\ Okitsu Citrus Research Station, Institute of Fruit and Tea Science, NARO, Okitsunaka-cho, Shimizu, Shizuoka 424-0292
}

\begin{abstract}
The satsuma mandarin (Citrus unshiu Marcow.) is one of the most eaten domestic fruits in Japan, and it is rich in $\beta$-cryptoxanthin $(\beta$-CRX). Recent studies suggested that $\beta$-CRX has bone-health benefits. The satsuma mandarin produced in Mikkabi, Shizuoka Prefecture, was accepted for the first time among fresh agricultural products as a "Food with functional nutrient claims." However, there are very few data concerning the differences among production areas and/or varieties in the $\beta$-CRX content and associations with fruit quality. In this study, we measured the $\beta$-CRX content of various kinds of this fruit harvested in major production centers and examined its relationship with the sugar content. As the results, we found that the cultivar with the lowest $\beta$-CRX content was gokuwase; the wase, nakate, and okute cultivars have similar levels of $\beta$-CRX. Furthermore, the $\beta$-CRX content is significantly and positively correlated with the sugar content in all production areas and varieties.
\end{abstract}

Key Words : carotenoid, foods with function claims, fruit quality, varietal difference

キーワード：品種間差，果実品質，カロテノイド，機能性表示食品

\section{緒言}

$\beta$-クリプトキサンチンは日本のウンシュウミカン（以 下, ミカン）に特徵的に多く含まれているカロテノイド色 素の一種である，我々はこれまで，ミカンを食べる習慣を 有する日本人の血中 $\beta$-クリプトキサンチン值は欧米人と 比べて顕著に高いことを見出してきた（Sugiura ら，2002; Sugiura ら, 2004). 現在, 国内主要ミカン産地である静岡 県浜松市北区三ヶ日町の住民を対象にした栄養疫学調査 (三ヶ日町研究) を継続的に行っているが，調査開始時の 血中 $\beta$-クリプトキサンチンレベルが高い者では, 骨粗しょ ら症や 2 型糖尿病, 動脈硬化症などの生活習慣病の発症リ スクが有意に低下寸ることをこれまでに見出している (Sugiura 5, 2012; Sugiura 5, 2015a, b; Sugiura 5, 2016a, b; Nakamura 5,2016 ).

2017 年 12 月 28 日 受付. 2018 年 4 月 18 日 受理.

* Corresponding author. E-mail: msugiura@dwc.doshisha.ac.jp

a 現在 : 同志社女子大学生活科学部食物栄養科学科 602-0893

京都市上京区今出川通寺町西入
一方，日本国内では2015年度より消費者庁において， 機能性表示食品制度が開始した（消費者庁，2015a）。本制 度では，事業者の責任でその科学的根拠を示すことで一定 のヘルスクレームの表示が可能になり，またサプリメント や加工食品だけでなく生鮮農産物もその対象となってい る. ミカンではこれまでに蓄積されている $\beta$-クリプトキ サンチンの機能性研究の成果をもとに, 2015 年 9 月に生 鮮農産物では初めて，JA みっかびの“三ヶ日みかん”が 骨の健康維持に役立つ機能性表示食品として登録された。

機能性表示食品では, 1 日当たりの拱取目安量を示すと ともにその機能性関与成分の含有量を表示しなくてはなら ないが，サプリメントや加工食品とは異なり，特に生鮮農 産物では品種や栽培条件，さらには栽培地域，収穫時期な ぞの影響で機能性関与成分の含有量にばらつきが生じるこ とが予想される。しかしながら，全国で栽培出荷されてい る様々なミカン品種の $\beta$-クリプトキサンチン含有量が産 地間や品種群間でどのように異なるか詳細に調べた報告例 は皆無である。一方，これまでにミカン果実中の $\beta$-クリ プトキサンチン含有量が糖度と有意に相関することが報告 されて扣り（漬崎・大城，2003），現在ミカンの等級選別 
の重要な指標である糖度（Brix 值）を近赤外線光センサー による非破壊選果機で全数検査することにより, 糖度が一 定基準より低いミカンを規格外として除外することで，機 能性表示の対象となる商品の $\beta$-クリプトキサンチン含有 量を担保している。しかしながら，これらの知見は演崎と 大城の知見に限られて打り（演崎 -大城, 2003), 他の産 地のミカンについての知見はほとんどない.

そこで本研究では, 産地間や品種群間での $\beta$-クリプト キサンチン含有量のばらつきを明らかにし，機能性表示食 品としての届出を行らら壳で必要な $\beta$-クリプトキサンチン 含有量の保証について一定の目安となる知見を得ることを 目的として, 国内の主要なミカン産地 4 県で生産されてい る極早生・早生・中生・晚生の各品種群での $\beta$-クリプト キサンチン含有量を分析し，産地間あるいは品種群間によ る差違を調査するとともに， $\beta$-クリプトキサンチン含有量 と果実品質（糖度）との関連性について検討した。

\section{材料および方法}

\section{1. 分析果実のサンプリング}

国内の主要なミカン産地である, 東海・近畿・四国・九 州地方の 4 県 (A 県〜 D 県) で生産出荷されている極早 生・早生・中生あるいは晚生品種についてそれぞれ 2015 年の最盛期にサンプリングを行った. サンプリングは, 極 早生品種群では 9 月下旬から 10 月中旬, 早生品種群では 11 月上旬から中旬, また中生・晚生品種群では 12 月上旬 から中旬にかけてサンプリングを行った。 な挌各農協での サンプリング段階では具体的な各品種の割合までは把握で きていないが, 各県での主要な品種名を第 1 表に示した. 各果実サンプルは非破壊選果機が導入されている選果場に おいて，等級別に出荷されたものを入手した。 また各県に ついて複数の農協からサンプリングを行った. な报極早生 品種が限られた地域でしか生産されていない県については 1 農協からのサンプリングとした。 また 1 農協で県内産ミ カンの過半数を占める県については 1 農協からのサンプ リングとした。 国内の各産地・農協で収穫されるミカン

第 1 表 試験に供したウンシュウミカン果実の品種

\begin{tabular}{ccc}
\hline \hline 品種群 & 品種名 & サンプリング時期 \\
\hline 極早生 & 高林 & 10 月上旬 \\
& ゆら早生 & 9 月下旬〜 10 月中旬 \\
& 日南 1 号 & 10 月中旬 \\
& 肥のあけぼの & 10 月上旬 \\
& 豊福早生 & 10 月上旬 \\
\hline 早生 & 宮川早生 & 11 月上旬 中旬 \\
& 興津早生 & 11 月上旬 中旬 \\
\hline 中生・晚生 & 南柑 20 号 & 12 月上旬 \\
& 青島 & 12 月上旬 $~$ \\
& 林 & 12 月中旬 \\
\hline
\end{tabular}

は，様々な品質管理のもと複数の等級（糖度や外観の質を 基本とした選果）で出荷されているため，基本的に上位階 級から下位階級のものまで, 生果として生産出荷されてい るすべての等級を分析の対象とした。 また各等級のミカン は基本的に最も出荷量の多い中心階級のもの（極早生品種 では $\mathrm{S}$ サイズ (果実の直径が $55 \mathrm{~mm}$ 以上 $61 \mathrm{~mm}$ 未満), 早 生や中生・晚生品種では主に M サイズ（同 $61 \mathrm{~mm}$ 以上 $67 \mathrm{~mm}$ 未満)）を用いたが，A県では比較的大玉な晚生 品種である‘青島温州’が主力品種であったため，L（同 $67 \mathrm{~mm}$ 以上 $73 \mathrm{~mm}$ 未満) 2L (同 $73 \mathrm{~mm}$ 以上 $80 \mathrm{~mm}$ 未満) サイズなど他の産地の晚生ミカンに比べて大玉階級のもの を対象とした。

各果実サンプルは入手後すぐに全果重（g）を測定し，外 果皮を剥皮した後に維管束などをできるだけ除去し，じょ らのら膜を含む状態を可食部として， $\beta$-クリプトキサン チンの分析に供した。それ攵れの果実サンプルは，ホモシ ナイザー（IKA T25 digital ULTRA-TURRAX ${ }^{\circledR}$, IKA，大阪） を用いて粉砕し，得られた果実ホモジネート液を用いて， 直ちにデジタル式糖度計（ATAGO PAL-1，（株）アタゴ，東 京）で糖度（Brix 值）を測定するとともに, HPLC 分析試 料とした.

\section{2. 果実中の $\beta$-クリプトキサンチン含有量の分析}

ウンシュウミカン果実 $100 \mathrm{~g}$ 中に含有される $\beta$-クリプト キサンチン量 $\left(\mathrm{mg} ・ 100 \mathrm{gFW}^{-1}\right)$ の分析はHPLC (1260 Infinity LC, アジレントテクノロジー(株), 東京) により 実施した. ガラス製の遠心管にホモジネートしたサンプル とピロガロールを入れた後, エタノールを加えてホモジナ イザーで粉砕した. 次に $60 \%$ 水酸化カリウム溶液を加え, 30 分間 $56^{\circ} \mathrm{C}$ でケン化処理を行った. ケン化処理を完了し た遠心管に，1\%塩化ナトリウムとへキサン（0.1\%ジブチ ルヒドロキシトルエン（以下，BHT）含有）を加え，ボル テックスミキサーで混合抽出を行った．遠心分離により分 かれた上層（有機層）を回収し，さらにへキサンによる 抽出を 3 回行った。 回収した有機層をエバポレーターで減 圧除去し $\left(40^{\circ} \mathrm{C}\right.$ 以下), $t$-ブチルメチルエーテル（以下, TBME) : メタノール (以下, $\mathrm{MeOH})(0.1 \%$ BHT, $1 \%$ 酢 酸アンモニウム含有) $(1: 1)$ 溶液に溶解し, HPLC 試料溶 液とした. HPLCのカラムは C30 カラム（YMC Carotenoid $\mathrm{S} 3 \mu 4.6 \mathrm{~mm} \times 100 \mathrm{~mm}$ i.d., （株）ワイエムシィ，京都）を用 いた。溶離液は $\mathrm{A}$ 液 $(\mathrm{MeOH} /$ ア七トニトリル（以下， $\left.\mathrm{MeCN}) / \mathrm{H}_{2} \mathrm{O} 7: 1: 2\right)$ と B 液（TBME/MeOH 9:1）の 2 種を 用い, 流速は $1.0 \mathrm{~mL} \cdot \mathrm{min}^{-1}, \mathrm{~A}$ 液: $\mathrm{B}$ 液 $=77.5: 22.5$ から分 析開始 20 分後には A 液: B 液 $=20: 80$ となるようにグラジ エント溶出を行った。検出波長は $450 \mathrm{~nm}$ を用いた. HPLC 分析のための検量線は，標品（ $\beta$-Cryptoxanthin ( $(3 \mathrm{R})-\beta, \beta$ Caroten-3-ol), 和光純薬工業(株), 大阪) をへキサンで溶 解し, 光路長が $1 \mathrm{~cm}$ の石英セルを用いて $449 \mathrm{~nm}$ での吸光 度を測定し，比吸光係数（2400）と測定した吸光度を用い て, 次式により $\beta$-クリプトキサンチン濃度を算出して作 
成した。

$$
\begin{aligned}
& \beta \text {-クリプトキサンチン }\left(\mu \mathrm{g} \cdot \mathrm{ml}^{-1}\right) \\
& =(\text { 吸光度 } \times 10000) / 2400
\end{aligned}
$$

濃度の異なる 3 種類の標品溶液により検量線を作成し た. 分析開始から 12.8 分後に溶出されるピークを $\beta$-クリ プトキサンチンと同定した.

本分析方法の再現性は, 濃度の異なる 6 サンプルを 5 回 抽出分析行った結果から，その変動係数は， $2.4 \% \sim 4.5 \%$ （平均 3.4\%）であることを確認した.

\section{3. 統計解析}

統計解析は SPSS ver 12.0J (SPSS Inc., Chicago, IL, USA) を用いて行った。 データはすべて平均標準偏差で示し た. 糖度や $\beta$-クリプトキサンチン含有量の品種間での比 較は Bonferroni の多群間比較検定を行った．糖度（Brix 值） と果実中 $\beta$-クリプトキサンチン含有量との回帰分析に掠 いては, Spearmanの単相関分析を行った.

\section{結果}

\section{1. 各産地における品種ごとにみた糖度と $\beta$-クリプトキ サンチン含有量}

各産地から収集した果実サンプルの全果実重 $(\mathrm{g})$ ，可食 部重 $(\mathrm{g})$, 糖度 (Brix 值), およびß-クリプトキサンチン 含有量 $\left(\mathrm{mg} ・ 100 \mathrm{gFW}^{-1}\right)$ を第2表に示した。いずれの産 地に沶いても, 早生品種群预よび中生・晚生品種群では極 早生品種群に比べて糖度と $\beta$-クリプトキサンチン含有量 は有意に高くなっていた．C県では中生品種の $\beta$-クリプト キサンチン含有量が早生品種よりも有意に高く，D県では 晚生品種よりも早生品種の方が有意に高かった。これに対 し，A県と B 県，またすべての産地を統合した場合の早生 と中生・晚生品種群間では $\beta$-クリプトキサンチン含有量 にいずれも有意な差は認められなかった。

\section{2. 糖度 (Brix 值) とß-クリプトキサンチン含有量との関係}

糖度と $\beta$-クリプトキサンチン含有量の単相関解析を行っ たところ，いずれの品種群またいずれの産地のミカンでも 有意な相関関係が認められ, 国内主要 4 県のすべてのミ カンを統合すると， $\mathrm{r}=0.688(p<0.001)$ であった（第 1 図 および第 2 図)。さらにそれぞれの県別に品種群ごとに糖

第 2 表 産地別・品種群別に久たウンシュウミカンの果実重量, 糖度执よび $\beta$-クリプトキサンチン含有量

\begin{tabular}{|c|c|c|c|c|c|c|c|c|c|c|}
\hline \multirow{2}{*}{$\begin{array}{l}\text { 産地県 } \\
\text { A 県 }\end{array}$} & \multirow{3}{*}{$\begin{array}{l}\text { 品種 } \\
\text { 極早生 } \\
\text { 早生 }\end{array}$} & \multirow{2}{*}{$\begin{array}{l}\mathrm{n} \\
70\end{array}$} & \multicolumn{2}{|c|}{$\begin{array}{c}\text { 果実重 } \\
(\mathrm{g})^{\mathrm{z}}\end{array}$} & \multicolumn{3}{|c|}{ 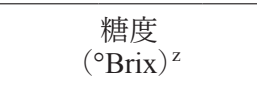 } & \multicolumn{3}{|c|}{$\begin{array}{c}\beta-\text { クリプトキサンチン } \\
\left(\mathrm{mg} \cdot 100 \mathrm{gFW}^{-1}\right)^{\mathrm{z}}\end{array}$} \\
\hline & & & 97.0 & $(12.7)$ & 10.2 & $(0.8)$ & $a^{y}$ & 1.30 & $(0.36)$ & $\mathrm{a}^{\mathrm{y}}$ \\
\hline & & 70 & 102.9 & $(10.5)$ & 11.5 & $(0.9)$ & $\mathrm{b}$ & 2.04 & $(0.34)$ & $\mathrm{b}$ \\
\hline & 晚生 & 420 & 170.1 & $(57.5)$ & 12.1 & (1.1) & $\mathrm{bc}$ & 1.97 & $(0.33)$ & $\mathrm{b}$ \\
\hline & Total & 560 & 152.5 & $(58.6)$ & 11.8 & (1.2) & & 1.89 & $(0.41)$ & \\
\hline \multirow[t]{4}{*}{ B 県 } & 極早生 & 80 & 101.0 & $(8.3)$ & 11.5 & $(1.2)$ & $a^{y}$ & 1.75 & $(0.32)$ & $a^{y}$ \\
\hline & 早生 & 80 & 98.1 & $(8.4)$ & 11.7 & $(1.0)$ & $\mathrm{a}$ & 1.96 & $(0.28)$ & $\mathrm{b}$ \\
\hline & 中生・晚生 & 80 & 90.4 & $(8.3)$ & 11.9 & $(1.1)$ & $\mathrm{b}$ & 1.97 & $(0.28)$ & $\mathrm{b}$ \\
\hline & Total & 240 & 96.5 & $(9.4)$ & 11.7 & (1.1) & & 1.89 & $(0.31)$ & \\
\hline \multirow[t]{4}{*}{ C 県 } & 極早生 & 210 & 92.8 & (22.9) & 10.1 & $(1.0)$ & $a^{y}$ & 1.40 & $(0.25)$ & $\mathrm{a}^{\mathrm{y}}$ \\
\hline & 早生 & 270 & 97.3 & $(8.7)$ & 11.4 & (1.1) & $\mathrm{b}$ & 1.81 & $(0.26)$ & $\mathrm{b}$ \\
\hline & 中生 & 285 & 92.0 & $(8.3)$ & 11.6 & $(1.3)$ & $\mathrm{b}$ & 1.94 & $(0.36)$ & $\mathrm{bc}$ \\
\hline & Total & 765 & 94.1 & $(14.2)$ & 11.1 & (1.3) & & 1.75 & $(0.37)$ & \\
\hline \multirow[t]{4}{*}{ D 県 } & 極早生 & 120 & 95.8 & $(8.5)$ & 11.2 & $(0.9)$ & $a^{y}$ & 1.69 & $(0.40)$ & $\mathrm{a}^{\mathrm{y}}$ \\
\hline & 早生 & 120 & 106.0 & (10.4) & 12.6 & (1.0) & $\mathrm{b}$ & 2.33 & $(0.30)$ & $\mathrm{b}$ \\
\hline & 晚生 & 110 & 114.5 & $(11.0)$ & 12.2 & $(0.9)$ & $\mathrm{bc}$ & 2.12 & $(0.30)$ & $\mathrm{bc}$ \\
\hline & Total & 350 & 105.2 & $(12.5)$ & 12.0 & $(1.1)$ & & 2.04 & $(0.43)$ & \\
\hline \multirow{3}{*}{\multicolumn{2}{|c|}{$\begin{array}{l}\text { 極早生（A-D 県） } \\
\text { 早生（A-D 県） } \\
\text { 中生・晚生（A-D 県） }\end{array}$}} & 480 & 95.5 & $(17.0)$ & 10.6 & $(1.2)$ & $a^{x}$ & 1.51 & $(0.37)$ & $a^{x}$ \\
\hline & & 540 & 100.1 & $(10.0)$ & 11.7 & (1.2) & $\mathrm{b}$ & 1.97 & $(0.35)$ & $\mathrm{b}$ \\
\hline & & 895 & 131.3 & $(54.5)$ & 12.0 & $(1.2)$ & $\mathrm{bc}$ & 1.98 & $(0.34)$ & $\mathrm{b}$ \\
\hline \multicolumn{2}{|l|}{ Total } & 1915 & 113.5 & $(42.1)$ & 11.6 & (1.3) & & 1.86 & $(0.40)$ & \\
\hline
\end{tabular}
$\left(\mathrm{mg} \cdot 100 \mathrm{gFW}^{-1}\right)$

z データはすべて平均值（標準偏差）で示す

y 各県での同一列の異なる英文字は Bonferroni 検定（5\%) で有意差のあることを示す

$\mathrm{x}$ 同一列の異なる英文字は Bonferroni 検定（5\%）で有意差のあることを示す 

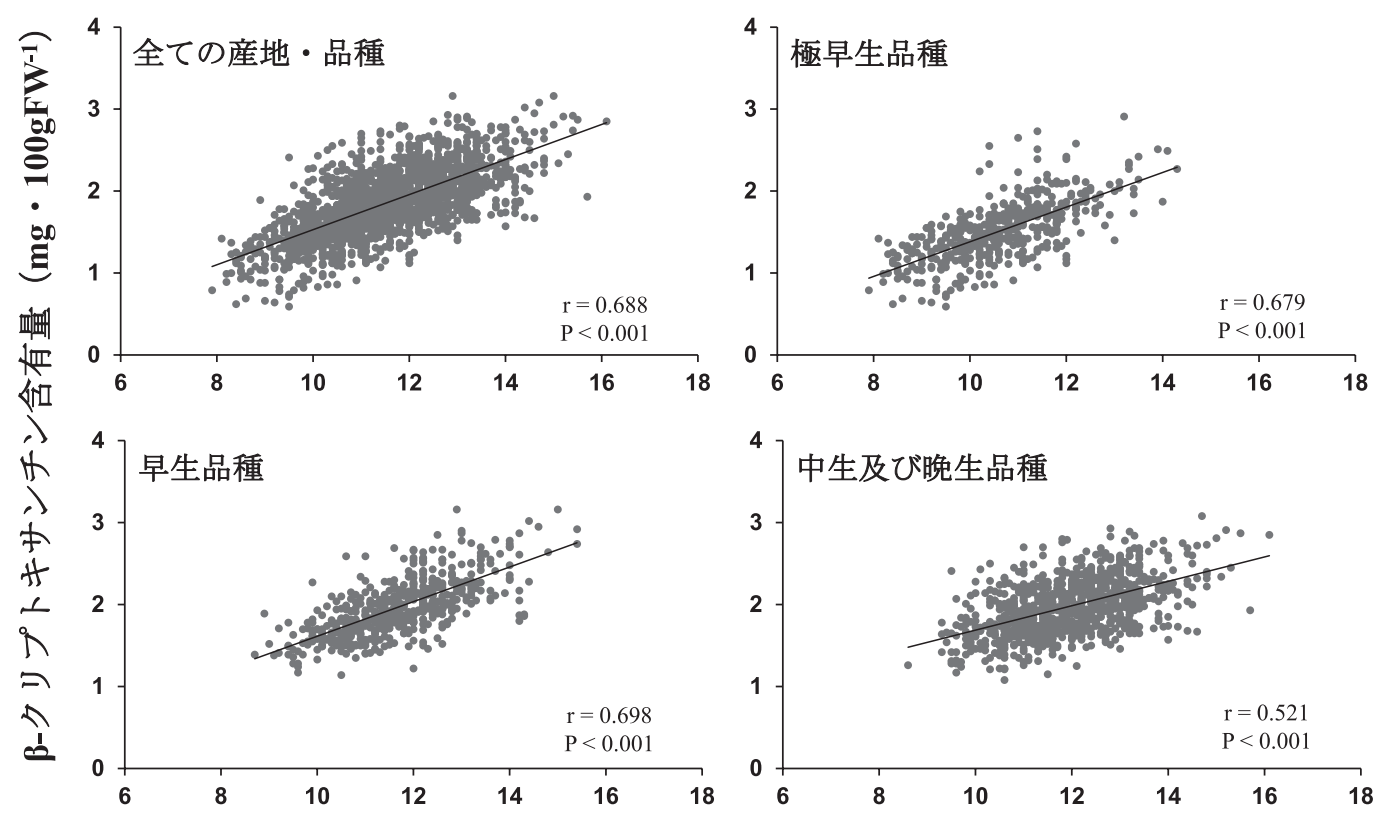

糖度 $\left({ }^{\circ}\right.$ Brix)

第 1 図 品種群別にみた国内主要産地に拈けるミカンの糖度と $\beta$-クリプトキサンチン含有量の散布図
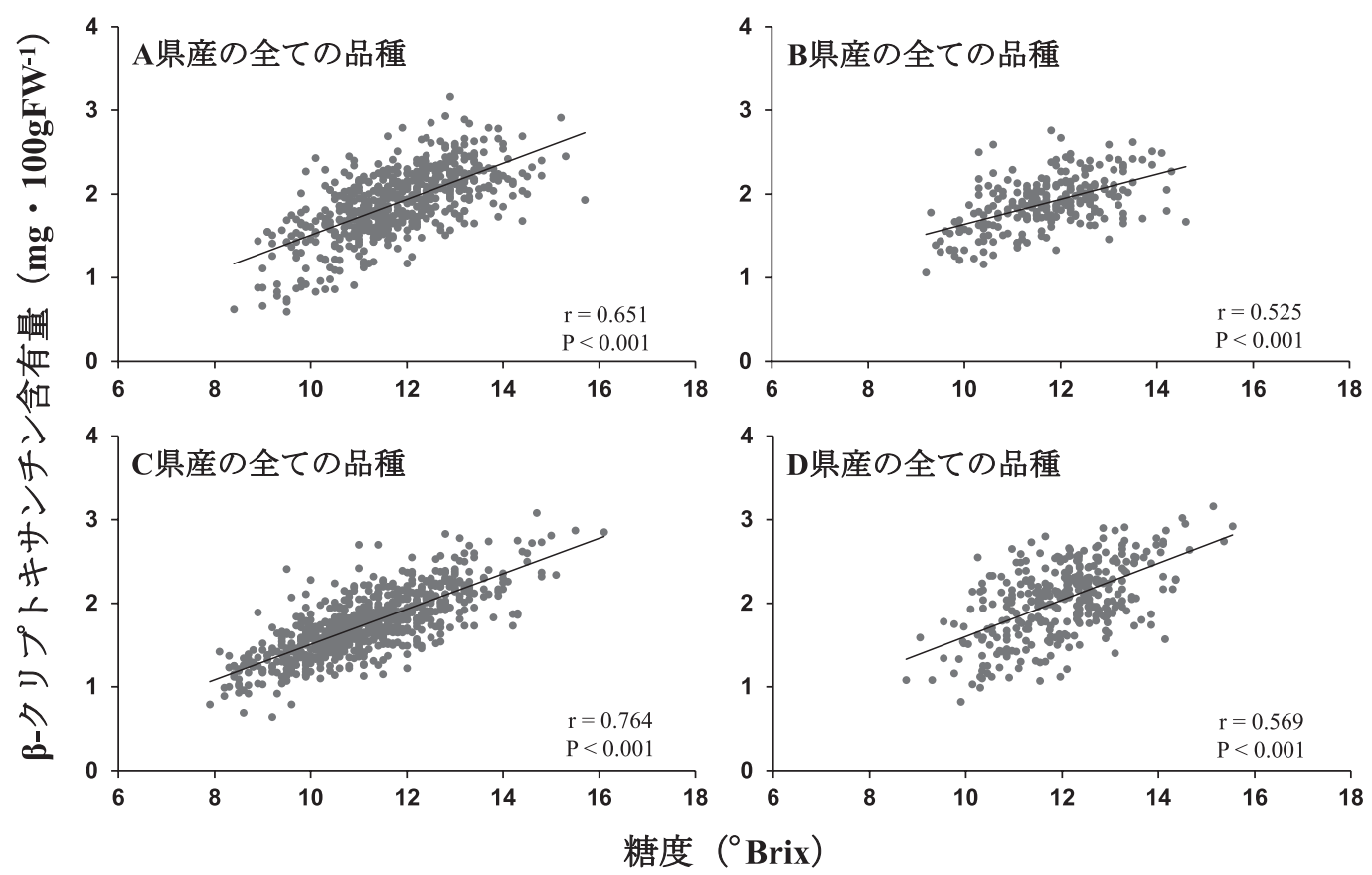

第2図 産地別にみた国内主要産地に拈けるミカンの糖度と $\beta$-クリプトキサンチン含有量の散布図

度とßークリプトキサンチン含有量の相関分析を行ったと ころ，多くの産地ではいずれの品種群に执いても糖度と $\beta$-クリプトキサンチン含有量は有意な正の相関が認められ たが， B 県の中生・晚生品種群また D 県の晚生品種群で有 意な相関は認められなかった（データ省略）。一方，今回 調査分析した果実では， $\beta$-クリプトキサンチン含有量と糖 度はいずれも果実重量と有意な相関は認められなかった。

\section{考察}

本研究に拈いて，国内の主要なミカン産地の果実サンプ ルを用いた $\beta$ クリプトキサンチン含有量の調査から，い ずれの産地においても, 早生品種群, 中生・晚生品種群で は極早生品種群に比べて糖度と $\beta$-クリプトキサンチン含 有量は有意に高く，また一部の産地に打ける中生や晚生品 種群を除くと多くの産地のミカンやいずれの品種群のミ 
カンでも $\beta$-クリプトキサンチン含有量は糖度と有意に正 相関することを明らかにした，これらの結果から，機能性 表示食品として販売する際には, 近赤外線光センサーによ る非破壊選果機で全数検査することにより, 糖度が一定基 準より低いミカンを規格外として除外することにより，機 能性表示の対象となる商品の $\beta$-クリプトキサンチン含有 量を担保することがいずれの産地でも可能であることが考 光らる。

また $\mathrm{A}$ 県抒よび $\mathrm{B}$ 県では, 早生品種群と中生・晚生品 種群とに $\beta$-クリプトキサンチン含有量に有意な差は認め られなかったが，C県の中生品種群は早生品種群よりも有 意に高く, これに対してD県では逆に晚生品種群よりも 早生品種群の方が $\beta$-クリプトキサンチン含有量は高かっ た. 早生品群と中生・晚生品群とで $\beta$-クリプトキサンチン 含有量の差が地域によって異なる原因は不明であるが，糖 度の結果でも同様の傾向がみられた. 各地域での栽培方法 は不明であるものの, シートマルチ栽培等により, より高 糖度なミカン栽培が可能になったために $\mathrm{D}$ 県に抢ける早 生品種群での $\beta$-クリプトキサンチン含有量も増加したの ではないかと考光られる。

果実中の $\beta$-クリプトキサンチン含有量はいずれの産地 のミカンあるいはいずれの品種群のミカンに沶いても糖度 と有意に正相関していたが，それぞれの県で品種群別に糖 度と $\beta$-クリプトキサンチン含有量の相関分析を行ったと ころ, $\mathrm{B}$ 県の中生・晚生品種群, また $\mathrm{D}$ 県の晚生品種群で 有意な相関は認められなかった (データ省略). その理由 として，層別化解析したことにより検体数が減り統計学的 な検出力が低下したこと, あるいは B 県の中生・晚生品 種群や D 県の晚生品種群でのミカン果実に扔ける糖度が 他の産地のものと比べると比較的均質で分布の幅が小さ かったためと考光られる。しかしながら, 糖度と $\beta$-クリ プトキサンチン含有量の相関関係は有意ではないものの, いずれも $\beta$ クリプトキサンチンを高含有して和り, ばら つきを考慮しても機能性表示食品として必要な $\beta$-クリプ トキサンチン量を担保できると考兄られる。 また本研究の 結果から, 分析対象とする果実の糖度が低いものから高い ものまで幅広く分布しているほど, 糖度と $\beta$-クリプトキ サンチン含有量の相関係数は高くなることが推察された.

一方, 糖度と $\beta$-クリプトキサンチン含有量の相関分析

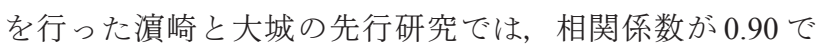
本研究の結果と比べて極めて高い相関関係が報告されてい る（演崎・大城，2003）。しかしながら, 演崎と大城の先 行研究では, 極早生から早生, 晚生, 貯蔵品種まで様々な 品種を対象に研究試験围場内で露地栽培からマルチ栽培, またコンテナ栽培など様々な栽培条件で収穫された果実を 分析対象として打り,さらには果実の未成熟段階から成熟 段階まで 3 段階でサンプリングしたものをすべて統合して 糖度と $\beta$-クリプトキサンチン含有量との相関分析を行っ ている。そのため実際には市場に流通しない糖度の低い果
実から高糖度の果実までを均等に幅広く分析対象にしてい るため, 糖度と $\beta$-クリプトキサンチン含有量に極めて高 い相関関係が認められたのではないかと考光られる。また 今回の研究では, 各品種群で様々な品種をまとめて分析対 象としたが，そ机沓れの品種で個別に $\beta$-クリプトキサン チン含有量のばらつきや糖度との相関関係を解析するこ とで，例えば早生品種でもどのような品種で特に $\beta$-クリ プトキサンチンと糖度との相関が強く認められるのかが 明らかになると考兄られ, 今後さらに調査研究する必要が ある。

また今回の研究ではいずれの産地に抢ける品種も最盛期 にサンプリングを行ったが，各品種が市場に流通する期間 は短いものでは極早生では 2 週間程度, 早生や晚生品種の 長いものでも 1 か月程度となっている. これらの出荷期間 中，シーズンのはじめと終わりでどの程度の差違があるか は不明である，出荷時期による $\beta$ ークリプトキサンチン含 有量の変動については今後さらに検証する必要がある。 ま た本調査研究は単年度での調査結果であるため, 一般化す るためには複数年次に渡った調査分析が必要である。ささら には他の産地のミカン, また貯蔵ミカンや施設で栽培され たハウスミカンについても検証する必要がある.

現在，機能性表示食品として受理登録されているミカン では毎日 $3 \mathrm{mg}$ の $\beta$-クリプトキサンチンを摂取することで 骨の健康維持に役立つとされて和り, $3 \mathrm{mg}$ の $\beta$-クリプト キサンチンを摂取するためのミカンの推奨摂取量を $270 \mathrm{~g}$ （可食部として M サイズのミカン拈よそ3個）としている （消費者庁，2015b）。今回分析した各産地のミカンに损い ても, 早生や中生・晚生品種群ではすべての果実で機能性 表示食品として必要な可食部 $90 \mathrm{~g}$ 当たり $1 \mathrm{mg}$ 以上の $\beta$-ク リプトキサンチン量を含有して和り，いずれの産地のミ カンでも機能性表示食品としての届出が可能と考兄られ る. 一方, 産地によっては極早生品種でのミカン果実中の $\beta$-クリプトキサンチン含有量が $90 \mathrm{~g}$ 当たり $1 \mathrm{mg}$ を下回る ものもあり, これらの産地の極早生ミカンについては, 秀 品や優品などの等級の高い（糖度の高い）ミカンに限れば 機能性表示食品としての届出は可能と考兄られる.

\section{摘 要}

近年，消費者庁で新たな食品表示法が施行され，生鮮農 産物も機能性表示食品の対象になった. ウンシュウミカン は日本国内で最も良く食される国産果実の一つであり， クリプトキサンチンを多く含屯，そのため，機能性表示食 品としての期待が高い. 本研究に扔いて, 国内主要産地の ウンシュウミカンに含ま机る $\beta$ ウクリプトキサンチン含有量 を各品種群で調査し, 果実品質（糖度）との関連について 検証を行った，その結果，ウンシュウミカン果実中の $\beta$-ク リプトキサンチン含有量は極早生品種群で最も低かった $\left(1.51 \pm 0.37 \mathrm{mg} \cdot 100 \mathrm{gFW}^{-1}\right)$. 一方, 早生 $(1.97 \pm 0.35 \mathrm{mg} ・$ $\left.100 \mathrm{gFW}^{-1}\right)$ や中・晚生 $\left(1.98 \pm 0.34 \mathrm{mg} \cdot 100 \mathrm{gFW}^{-1}\right)$ 品種 
群では極早生品種群に比べて有意に高く, これらの品種群 では同程度の $\beta$-クリプトキサンチンが含有されていた. また果実中の $\beta$-クリプトキサンチン含有量はいずれの産 地・品種群のミカンであっても糖度と有意に正相関するこ とが明らかとなった. 今後, 各産地での機能性表示食品と しての表示が期待される.

謝 辞 本調査研究は, 平成 27 年度補正予算「革新的 技術開発・緊急展開事業（らち地域戦略プロジェクト）」 (平成 $28 \sim 30$ 年度), 拈よび全国柑橘消費拡大協議会か らの委託研究の一部として行われた。 ここに深謝の意を表 する.

\section{引用文献}

演崎 櫻・大城 晃. 2003. ウンシュウミカンの果肉に含 まれる $\beta$-クリプトキサンチン量に対する栽培方法や 貯蔵の影響. 静岡柑試研報. 32: 1-6.

Nakamura, M., M. Sugiura, K. Ogawa, Y. Ikoma and M. Yano. 2016. Serum $\beta$-cryptoxanthin and $\beta$-carotene derived from Satsuma mandarin and brachial-ankle pulse wave velocity: The Mikkabi cohort study. Nutr. Metab. Cardiovasc. Dis. 26: 808-814.

消費者庁. 2015a． 食品関連事業者の方へ「機能性表示食 品制度」が始まります！〈http://www.caa.go.jp/foods/pdf/ syokuhin1443.pdf $>$.

消費者庁. 2015b. 機能性表示食品の届出情報（商品名： 三ヶ日みかん〈https://www.fld.caa.go.jp/caaks/cssc02/ ?recordSeq=0IKO41603310760101 $\rangle$.

Sugiura, M., M. Kato, H. Matsumoto, A. Nagao and M. Yano. 2002. Serum concentration of $\beta$-cryptoxanthin in Japan reflects the frequency of Satsuma mandarin (Citrus unshiu
Marc.) consumption. J. Health Sci. 48: 350-353.

Sugiura, M., H. Matsumoto, M. Kato, Y. Ikoma, M. Yano and A. Nagao. 2004. Multiple linear regression analysis of seasonal changes in the serum concentration of $\beta$-cryptoxanthin. J. Nutr. Sci. Vitaminol. 50: 196-202.

Sugiura, M., M. Nakamura, K. Ogawa, Y. Ikoma and M. Yano. 2012. High serum carotenoids associated with lower risk for bone loss and osteoporosis in post-menopausal Japanese female subjects: Prospective cohort study. PLOS ONE 7: e52643.

Sugiura, M., M. Nakamura, K. Ogawa, Y. Ikoma and M. Yano. 2015a. High serum carotenoids associated with lower risk for developing type 2 diabetes among Japanese subjects: Mikkabi prospective cohort study. BMJ Open Diabetes Res. Care 3: e000147.

Sugiura, M., M. Nakamura, K. Ogawa, Y. Ikoma and M. Yano. 2015b. High serum carotenoids associated with lower risk for metabolic syndrome and its components among Japanese subjects: Mikkabi prospective cohort study. Br. J. Nutr. 114: 1674-1682.

Sugiura, M., M. Nakamura, K. Ogawa, Y. Ikoma and M. Yano. 2016a. High vitamin $\mathrm{C}$ intake with high serum $\beta$-cryptoxanthin associated with lower risk for osteoporosis in post-menopausal Japanese female subjects: Mikkabi cohort study. J. Nutr. Sci. Vitaminol. 62: 185-191.

Sugiura, M., M. Nakamura, K. Ogawa, Y. Ikoma and M. Yano. 2016b. High serum carotenoids are associated with lower risk for developing elevated serum alanine aminotransferase among Japanese subjects: Mikkabi prospective cohort study. Br. J. Nutr. 115: 1462-1469. 